\title{
Evidence of separate karyotype evolutionary pathway in Euglossa orchid bees by cytogenetic analyses
}

\author{
ANDERSON FERNANDES ${ }^{1}$, HUGO A. WERNECK ${ }^{2}$, SILVIA G. POMPOLO ${ }^{2}$ and DENILCE M. LOPES ${ }^{2}$ \\ ${ }^{1}$ Departamento de Ciências Biológicas, Universidade do Estado de Mato Grosso, \\ MT Rodovia MT, 358, Km 07, Jardim Aeroporto, 78300-000 Tangará da Serra, MT, Brasil \\ ${ }^{2}$ Departamento de Biologia Geral, Universidade Federal de Viçosa, Av. P.H. Rolfs, s/n, 36570-000 Viçosa, MG, Brasil
}

Manuscript received on February 12, 2011; accepted for publication on September 26, 2011

\begin{abstract}
Euglossini are solitary bees considered important pollinators of many orchid species. Information regarding chromosome organization is available for only a small number of species in this group. In the present work, the species Euglossa townsendi and E. carolina were analyzed by cytogenetic techniques to collect information that may aid the understanding of their evolution and chromosomal organization. The chromosome number found was $n=21$ for males and $2 n=42$ for females in the two species. The distribution and amount of heterochromatin regions differed in the two species analyzed, where they were classified as "high" or "low" heterochromatin content, similarly to what has already been performed in social bee species of the genus Melipona. Banding patterns found in this study suggest that other mechanisms may have occurred in the karyotype evolution of this group, unlike those suggested for social bees and ants. Karyotype evolution of solitary bees appears to have occurred as an event separate from other hymenopterans and did not involve chromosome fissions and heterochromatin amplification.
\end{abstract}

Key words: Cytogenetics, Euglossini, heterochromatin, karyotypic evolution.

\section{INTRODUCTION}

Among insects, the Hymenoptera order attracts great interest from the field of cytogenetics. Different bee (review in Rocha et al. 2003) and ant species (Lorite and Palomeque 2010) have already been investigated. However, there is almost no information on genome organization at the chromosomal level of some groups. One example includes the bee Euglossini. These bees exhibit solitary behavior and have received attention in recent years in particular because they are effective

Correspondence to: Denilce Meneses Lopes

E-mail: denilce.lopes@ufv.br pollinators of nearly 700 orchid species (Ramírez 2005). For this reason they are also known as "orchid bees".

Among the five genera of Euglossini, Euglossa Latreille (1802) is the most diverse, composed of six subgenera with about 122 species (Nemésio 2009). This number may be much higher as there are constant revisions and faunal surveys needed, as well as the group taxonomy is extremely complicated due to the large number of morphological similarities.

Cytogenetics of the Euglossini group is currently restricted to few species. Eltz et al. (1997) 
determined chromosome numbers of the Euglossa cyanaspis and E. hyacinthina species $(\mathrm{n}=21$ and $n=20$, respectively), and also confirmed that chromosome morphology was submetacentric in both species. In the same study, the researchers cited that Kerr and Laidlaw (1956) determined the chromosome number for the Eufriesea violacea species as $n=16$. This species was further studied with other techniques (Gomes et al. 1998). In this study, the authors used the techniques of $\mathrm{C}$ and $\mathrm{G}$ banding to obtained greater detail on heterochromatin distribution and a more secure pairing between homologues. They also established the chromosome number for the species as $2 n=30$ in all submetacentric chromosomes. Another study was performed with a species of Euglossa (unidentified) in which the authors observed $\mathrm{n}=21$ for males, and reported marking by the Ag-NOR technique (silver impregnation - Nucleolar Organizer Region) in five chromosomes (Maffei et al. 2001).

Considering the ecological importance of these bees and the lack of cytogenetic studies with Euglossini species, the present work aimed to expand the cytogenetic information by analyzing two species of the Euglossa genera, E. (Euglossa) carolina Nemésio 2009 and E. (Euglossa) tonwsendi Cockerell (1904), using conventional staining, C band, restriction enzymes and fluorochromes for better understanding of the karyotype evolution of these bees. restriction enzymes and fluorochromes for better understanding of the karyotype evolution of these bees.

\section{MATERIALS AND METHODS}

Individuals captured in bamboo tube nest traps were used in the present study (as describle by Camillo et al. 1995). Euglossa carolina was collected in Cataguases, MG, Brazil, (three nest obtaining a total of 12 individuals) and E. tonwsendi in the city of Viçosa, MG, Brazil (two nest obtaining a total of 9 individuals). The cerebral ganglia of larvae in the final defecation stage were removed and used for chromosomic preparations. Metaphase chromosomes were obtained according to the methodology proposed by Imai et al. (1988).

After obtaining metaphase chromosomes, the slides were subjected to staining techniques. For the conventional staining, a solution of $4 \%$ Giemsa in Sörensen buffer, $\mathrm{pH}$ 6.8, was used for 15 minutes. The $\mathrm{C}$ banding (BSG method: Bariumhydroxide/ Saline/Giemsa) was performed as suggested by Rocha and Pompolo (1998). Sequential staining with the fluorochromes chromomycin A3 (CMA3) and DAPI (4'-6- diamino-2-phenylindole) was carried out according to Schweizer (1980) with the modifications proposed by Rocha et al. (2002). Quinacrine mustard was used according to Schmid (1980). G banding was carried according to Seabright (1971) and restriction banding with DraI (AAA/TTT) and HaeIII (CC/GG) as reported by Gosálvez et al. (1987).

The slides were then analyzed under an Olympus BX60 light/fluorescence microscope with immersion objective, seeking to observe an average of 10 metaphases per slide. For karyotype mounting, the chromosomes were arranged according to the classification proposed by Levan et al. (1964).

\section{RESULTS}

EUGLOSSA TONWSENDI

Euglossa townsendii presented submetacentric chromosomes, $2 \mathrm{n}=42$ for females and $\mathrm{n}=21$ for males (Fig. 1), with heterochromatin blocks on the pericentromeric region of the long arm, and in some chromosomes on the short arm (Fig. 1B). An interstitial and a telomeric block were also observed in three chromosomes (Fig 1B).

When treated with the fluorochromes DAPI and CMA3 the pericentromeric heterochromatin showed to be rich in $\mathrm{AT}$ bases (markings $\mathrm{DAPI}^{+}$and CMA3-, Fig. 1C and D, respectively), except for the telomeric region of the long arm of chromosomes 2, 3, and 7 which indicated minimal markings by CMA3 (Fig. 1D). 
Positive $G$ bands were observed in both euchromatin and heterochromatin regions (Fig 2A). Some positive $\mathrm{G}$ bands were also $\mathrm{QM}^{+}$, especially in the pericentromeric and telomeric regions, indicating that they are rich in AT sequences (Fig $2 \mathrm{~A}$ and $2 \mathrm{~B})$.

By using the restriction enzyme HaeIII (target site $\mathrm{CC} / \mathrm{GG}$ ) followed by conventional staining, it was possible to visualize enzyme activity at the end of one arm of the 14 chromosomes of the haploid set (Fig. 2C). However, when the enzyme was used sequentially with DAPI, a new marking pattern was encountered (Fig. 2D). Remarkable were the markings on the pericentromeric and terminal regions of the arms of most chromosomes. Two chromosomes of the haploid set were highlighted because they have very intense markings at the terminal region of one arm. Results of the treatment with the enzyme DraI (recognition site AAA/TTT) (Fig. 2E and F) were very similar to those found for HaeIII. Four chromosomes of the diploid set showed strong markings at the end of one arm.

A)

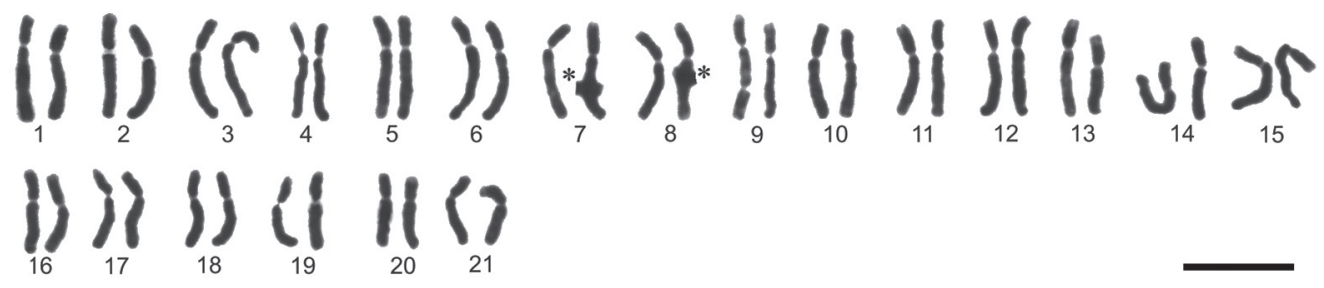

B)
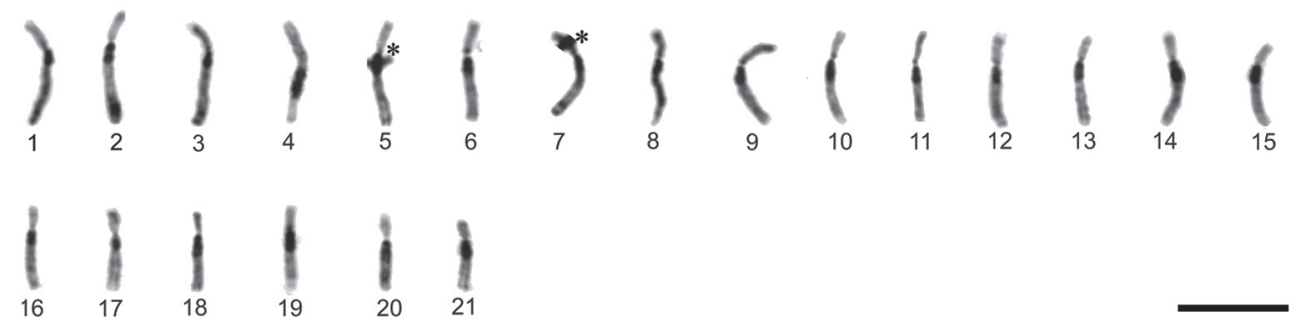

C)

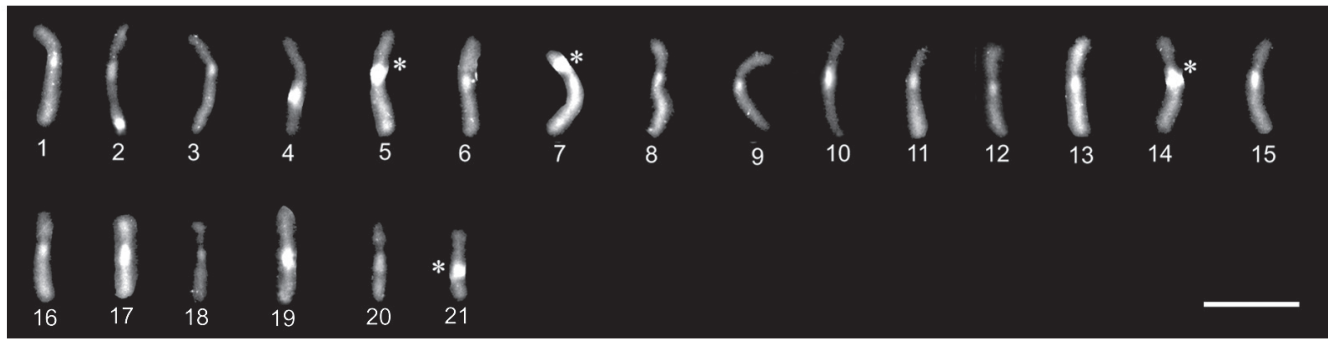

D)

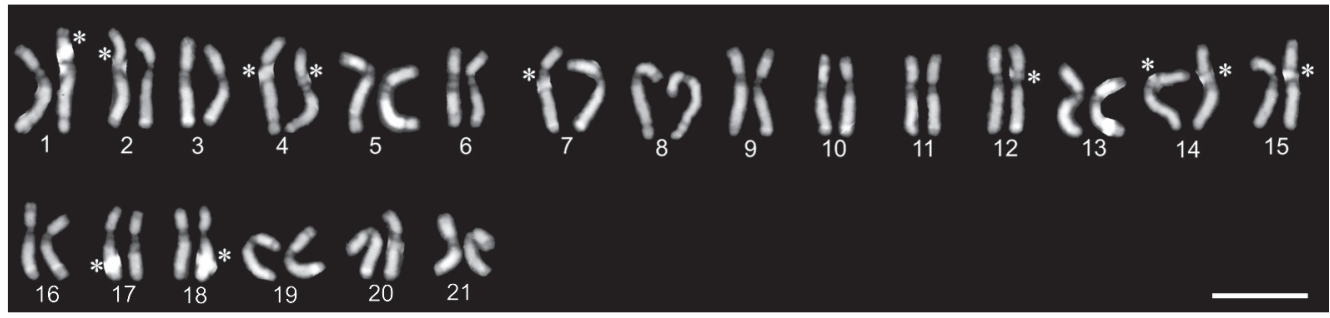

Figure 1 - Karyotypes of Euglossa townsendi, $\mathrm{n}=21$ (male) and $2 \mathrm{n}=42$ (female). Conventional staining (A). C-banding (B). DAPI fluorochrome (C). CMA3 fluorochrome (D). The asterisk indicates sites of chromosome overlap. Scale bar $=5 \mu \mathrm{m}$. 

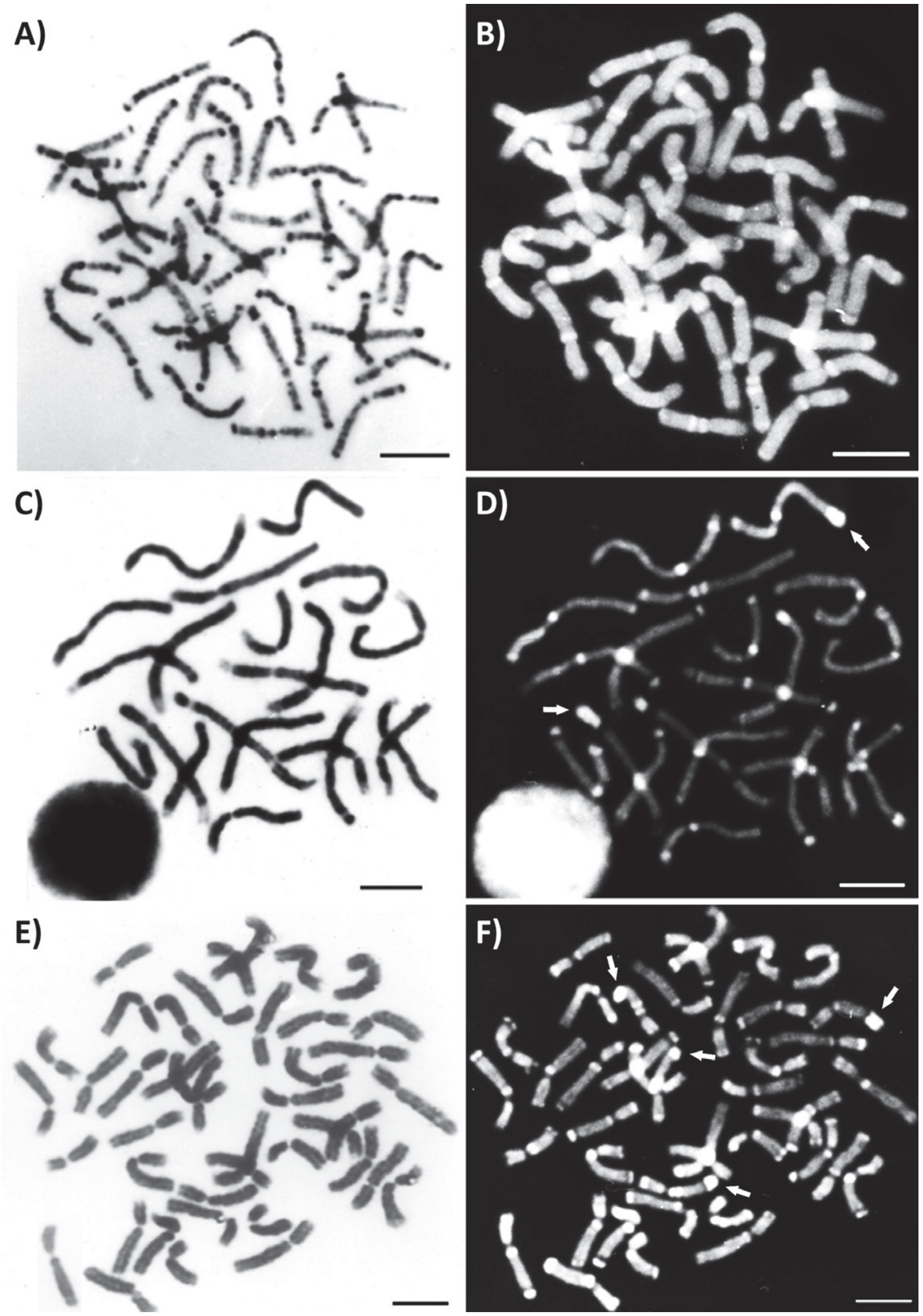

Figure 2 - Metaphases of Euglossa townsendi. G-band (A). Quinacrine mustard used sequentially to G-band (B). Restriction enzyme HaeIII with conventional staining (C) and DAPI (D). Restriction enzyme DraI with conventional staining (E) and DAPI (F). Arrows indicate site of intense markings. Scale bar $=5 \mu \mathrm{m}$. 


\section{EUGLOSSA CAROLINA}

The chromosome number of this species was $2 n=42$ for females and $\mathrm{n}=21$ for males, and all chromosomes present submetacentric morphology (Fig. 3A and B). In some chromosomes, it was possible to visualize the presence of secondary constrictions. Chromosomes were almost entirely heterochromatic with exception of teloremic regions (Figure 3B).

The fluorochromes showed a centromeric region with composition rich in AT (DAPI+), while GC-rich regions were verified throughout

A)

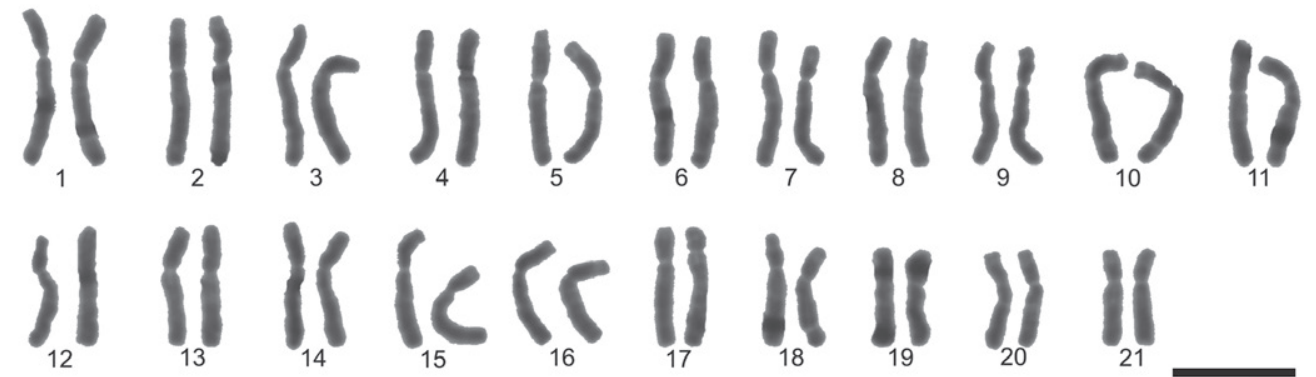

B)
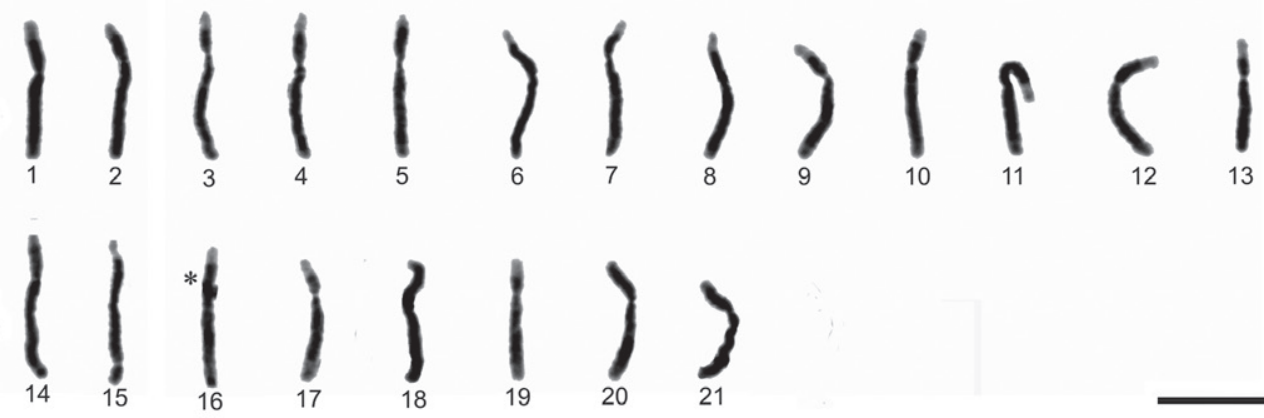

C)

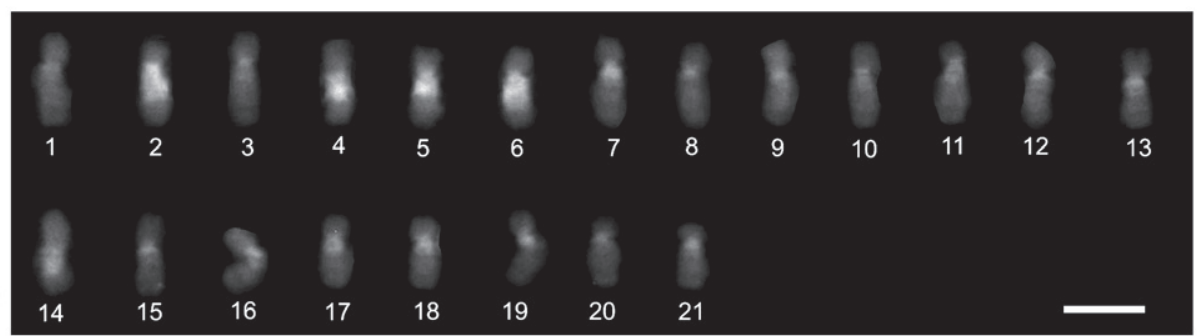

D)

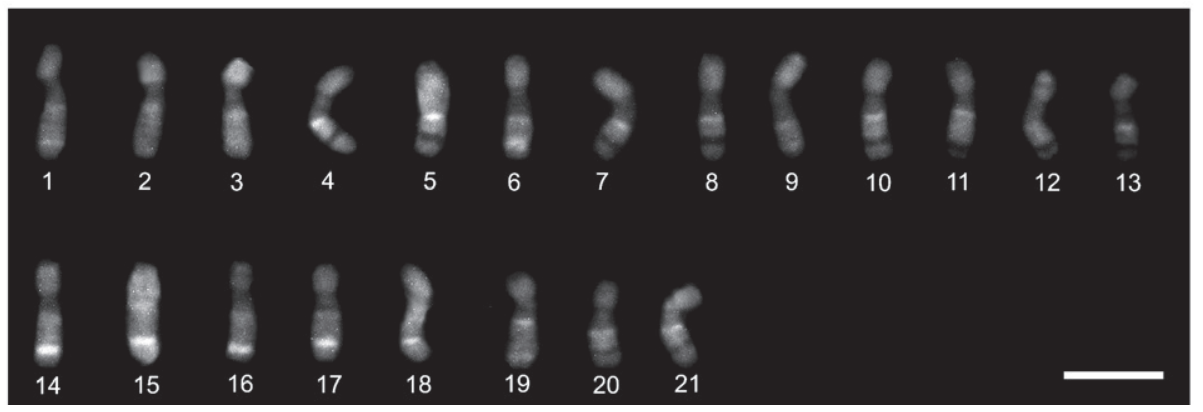

Figure 3 - Karyotypes of Euglossa carolina, $n=21$ and $2 n=42$. Conventional staining of female (A). C-banding (B). DAPI fluorochrome (C). $\mathrm{CMA}_{3}$ fluorochrome (D). The asterisk indicates sites of chromosome overlap. Scale bar $=5 \mu \mathrm{m}$. 
the chromosome where it was possible to observe several bands (Fig. 3C and D). Heterochromatin therefore appears to be heterogeneous with blocks rich in AT and others in GC.

\section{DISCUSSION}

\section{Chromosomal ORganizATION}

Only two Euglossa species have been studied cytogenetically, E. cyanaspis and E. hyacinthina (Eltz et al. 1997), and chromosome numbers presented by these species are $n=21$ and $n=20$, respectively. The chromosome numbers of the two species studied in the present work were $\mathrm{n}=21$. Conservation of the chromosome number (or little change) in bees appears to be a feature commonly found in these species.

Secondary constrictions indicated by conventional staining in E. carolina can be associated with the Nucleolar Organizer Region (NOR). The same pattern has been previously observed in Euglossa sp. by Maffei et al. (2001), who matched positive CMA3 marks on five chromosomes. Further confirmation should be obtained by specific techniques such as Ag-NOR or in situ hybridization . However, good results with Ag-NOR in bees are restricted to only few species (Maffei et al. 2001, Duarte et al. 2009) and in situ hybridization is not yet widely used in this group.

Variations regarding heterochromatin quantity and location were observed between the $E$. tonwsend $i$ and $E$. carolina species. While E. tonwsendipresented very little heterochromatin, a large quantity of heterocromatin was observed in E. carolina located in the interstitial region, with euchromatin restricted to chromosome ends. A pattern similar to E. carolina was found in Eufriesea violacea (Gomes et al. 1998), another Euglossini bee.

In the genus Melipona the pattern of heterochromatin distribution allowed division of these bees into two groups: one showing a high heterochromatin content and the other a low content (Rocha and Pompolo 1998). Compared to the Euglossini bees studied so far, E. tonwsendi could be classified as belonging to the group of low heterochromatin content with pericentromeric distribution, while E. carolina to the group of high heterochromatin content with interstitial distribution throughout the chromosome.

Fluorochrome staining showed that positive $\mathrm{C}$ bands were predominantly $\mathrm{DAPI}^{+}$with the exception of a few $\mathrm{CMA}^{+}$heterochromatic blocks in E. carolina chromosomes. This demonstrates that in E. carolina the heterochromatin is not homogeneous, which may be related to distinct sequences that make up the heterochromatin and are not highlighted by $\mathrm{C}$ banding. Usually these few $\mathrm{C}^{+} / \mathrm{CMA}^{+}$regions of the genome are associated with NORs (Maffei et al. 2001, Rocha et al. 2002, 2003, Brito et al. 2005).

The G-banding technique indicated rich patterns of bands in E. tonwsendi in both euchromatic and heterochromatic regions of all chromosomes (Figure 2A). When followed by QM, some $\mathrm{G}^{+}$bands were also shown as $\mathrm{QM}^{+}$(rich in AT bases), especially those located in pericentromeric regions and at the end of one arm (Figure 2B).

Despite the contrasting recognition sites, both restriction enzymes HaeIII (CC/GG) and DraI (AAA/TTT) cleaved DNA at the chromosomes ends of E. townsendi. (Fig. 2D and F).

This result seems contradictory since fluorochromes bind to DNA and restriction enzymes (RE) initially function by removing DNA. However, a different action mechanism of some REs should be mentioned which would result in chromatin decondensation (Mezzanote and Ferrucci 1984, Miller et al. 1984). This decondensation may increase accessibility to DNA providing a greater number of binding sites between fluorochromes (Verma and Babu 1995).

\section{HETEROCHROMATIN CONTENT AND KARYOTYPE EVOLUTION}

One mechanism proposed to explain karyotype evolution in the Hymenoptera order is centric fission. This mechanism is supported by the 
Minimum Interaction Theory proposed by Imai et al. (1994). It predicts that the karyotype evolved to minimize DNA damage due to interactions between the chromosomes by decreasing the size of chromosomes resultant from centric fission, which would increase the chromosome number. To regain stability in the fission region, there would have occurred the in tandem growth of heterochromatin in this region, leading to chromosomes with a heterochromatic arm (Imai et al. 1988). In Meliponini, the karyotype analyses of 70 species (review Rocha et al. 2003) appeared to indicate that for most species the karyotypic changes in these organisms are in accordance with events predicted in the Theory of Minimal Interaction. In the Melipona genus however, it appears that heterochromatin was added without being preceded by fission (Rocha et al. 2003).

In Euglossa other mechanisms may have caused karyotype evolution as individuals have high chromosomes numbers, higher than other bees species. The chromosomes are large and present submetacentric morphology which is contrary to the characteristics predicted in the Theory of Minimal Interaction. Moreover, different patterns of heterochromatin distribution are encountered, similar to that seen in Melipona.

Therefore, karyotype evolution of the Hymenoptera order (or at least in solitary bees) seems to have occurred in separate events involving fission followed by heterochromatin amplification. Therefore, this study provides important data on solitary bees. However due to the small number of species studied these questions cannot yet be answered with certainty but as the number of Euglossini species analyzed increases the processes involved in the karyotype evolution may be better understood.

\section{ACKNOWLEDGMENTS}

The authors thank Fundação de Amparo à Pesquisa do Estado de Minas Gerais (FAPEMIG),
Fundação de Amparo à Pesquisa do Estado de Mato Grosso (FAPEMAT) and Conselho Nacional de Desenvolvimento Científico e Tecnológico (CNPq) for the financial support.

\section{RESUMO}

Os Euglossini são abelhas solitárias consideradas importantes polinizadores de muitas espécies de orquídeas. Somente um pequeno número de espécies desse grupo possui informações sobre sua organização cromossômica. Neste trabalho as espécies Euglossa townsendi e E. carolina foram analisadas por técnicas citogenéticas a fim de obter informações que auxiliem no entendimento de sua evolução e organização cromossômica. O número cromossômico encontrado foi $\mathrm{n}=21$ para os machos e $2 n=42$ para as fêmeas das duas espécies. A distribuição e a quantidade de heterocromatina diferem nas duas espécies analizadas e podem ser classificadas como alta e baixa quantidade de heterocromatina, similarmente como já foi feito anteriormente para espécies de abelhas sociais do gênero Melipona. O padrão de bandeamento encontrado no presente trabalho sugere que outros mecanismos podem estar envolvidos na evolução cariotípica do grupo, diferente daqueles sugeridos para as abelhas sociais e formigas. A evolução cariotípica de abelhas solitárias parece ter acontecido por eventos distintos que não envolveram fissões cromossômicas e amplificação da heterocromatina.

Palavras-chave: Citogenética, Euglossini, heterocromatina, evolução cariotípica.

\section{REFERENCES}

Brito RM, POMPOLO SG, MARTINS MF, BARRos EG AND SAKAMOTO-HoJo ET. 2005. Cytogenetic characterization of two Partamona species (Hymenoptera, Apinae, Meliponini) by fluorochrome staining and localization of 18 rDNA clusters by FISH. Cytologia 70: 373-380.

Camillo E, Garófalo CA, Serrano JC and Muccillo G. 1995. Diversidade e abundância sazonal de abelhas e vespas solitárias em ninhos armadilhas (Hymenoptera, Apocrita, Aculeata). Rev Bras Ent 39(2): 459-470.

DUARTE OMP, MARTINS CCC, WALDSCHMIDT AM AND Costa MA. 2009. Occurrence of multiple nucleolus organizer regions and intraspecific karyotype variation in Scaptotrigona xanthotricha Moure (Hymenoptera, Meliponini). Genet Mol Res 8(3): 831-839. 
Eltz T, SCHIMID M AND RouBIK DW. 1997. Haploid karyotypes of two orchid bees (Hymenoptera: Apidae, Euglossini). J Ent Soc 70(2): 142-144.

Gomes LF, BRITO RM, POMPOLO SG, CAMPOS LAO AND PERUQUETTI RC. 1998. Karyotype and C- and G-banding patterns of Eufriesea violacea (Hymenoptera: Apidae, Euglossinie). Hereditas 128: 73-76.

GosÁlvez J, Bella JL, LÓPEZ-FernANdez C AND MEZZANOTTE R. 1987. Correlation between constitutive heterochromatin and restriction enzyme resistant chromatin in Arcyptera tornosi (Orthoptera). Heredity 59: $173-180$

IMAI HT, TAYLOR RW, CROSLAND MWJ AND CROZIER RH 1988. Modes of spontaneous evolution in ants with reference to the minimum interaction hypothesis. Jpn J Genet 63: 159-185.

IMAI HT, TAYLOR RW AND CROZIER RH. 1994. Experimental bases for the minimum interaction theory. Chromossome evolution in ants of the Myrmecia pilosula species complex (Hymenoptera: Formicidae: Myrmecinae). Jpn J Genet 69: 137-182.

KerR WE AND LAIDLAW HH. 1956. Genetics of bees. Adv Genet 8: 109-153.

LEVAN A, Fredga K AND SANDBERG AA. 1964. Nomenclature for centromeric position on chromosomes. Hereditas 52: 201-220.

LORITE P AND PAlOMEQUE T. 2010. Karyotype evolution in ants (Hymenoptera: Formicidae), with a review of the known ant chromosome numbers. Myrmecol News 13: 89-102.

MAFFEI EMD, POMPOLO SG, SILVA-JÚNIOR JC, CAIXEIRO APA, ROCHA MP AND DERGAM JA. 2001. Silver staining of nucleolar organizer regions (NOR) in some species of Hymenoptera (bees and parasitic wasps) and Coleoptera (lady-beetle). Cytobios 104: 119-125.
MeZzANOTE R AND FERRUCCI L. 1984. Alteration induced in mouse chromosomes by restriction endonucleases. Genetica 64: 123-128.

Miller DA, Gosden JR, Hastie ND AND Evans HJ. 1984. Mechanism of endonucleases banding of chromosomes. Exp Cell Res 155: 294-298.

NEMÉSIO A. 2009. Orchid bees (Hymenoptera: Apidae) of the Brazilian Atlantic Forest. Zootaxa (Auckland) 2041: $1-242$.

RAMíREZ S. 2005. Euglossa paisa, a new specie of orchid bee from the Colombian Andes (Hymenoptera: Apidae). Zootaxa 1065: 51-60.

RochA MP AND POMPOLO SG. 1998. Karyotypes and heterocromatin variation (C-bands) in Melipona species (Hymenoptera: Apidae, Maliponinae). Genet Mol Biol 21: 41-45.

Rocha MP, POMPOLO SG AND CAMPOS LAO. 2003. Citogenética da tribo Meliponini (Hymenoptera, Apidae). p. 311-320. In: MELO GAR and ALVES-DOS-SANTOS I (Eds), Apoidea Neotropica: Homenagem aos 90 Anos de Jesus Santiago Moure. Editora UNESC, Criciúma, 320 p.

Rocha MP, Pompolo SG, Dergam JA, Fernandes A AND CAMPOS LAO. 2002. DNA characterization and karyotypic evolution in the bee genus Melipona (Hymenoptera, Meliponini). Hereditas 136: 19-27.

SCHIMD M. 1980. Chromosome banding in Amphibia. Chromossoma 77: 83-103.

SCHWEIZER D. 1980. Simultaneous fluorescent staing of $\mathrm{R}$ bands and specific heterochromatic region (DA-DAPI bands) in human chromosomes. Cytogenet Cell Genet 27: 190-193.

SEABRIGHT M. 1971. A rapid banding technique for human chromosomes. Lancet. 2: 971-972.

VERMA RS AND BABU A. 1995. Human chromosome. New York: McGraw-Hill, 419 p. 